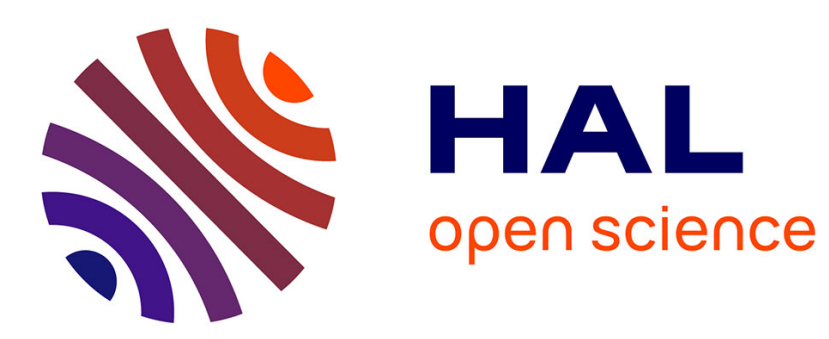

\title{
Phaeodactylum tricornutum
}

Chris Bowler, Angela Falciatore

\section{To cite this version:}

Chris Bowler, Angela Falciatore. Phaeodactylum tricornutum. Trends in Genetics, 2019, 35 (9), pp.706-707. 10.1016/j.tig.2019.05.007 . hal-02380836

\section{HAL Id: hal-02380836 \\ https://hal.science/hal-02380836}

Submitted on 20 Dec 2021

HAL is a multi-disciplinary open access archive for the deposit and dissemination of scientific research documents, whether they are published or not. The documents may come from teaching and research institutions in France or abroad, or from public or private research centers.
L'archive ouverte pluridisciplinaire HAL, est destinée au dépôt et à la diffusion de documents scientifiques de niveau recherche, publiés ou non, émanant des établissements d'enseignement et de recherche français ou étrangers, des laboratoires publics ou privés.

\section{다)(1) $(5$}

Distributed under a Creative Commons Attribution - NonCommercial| 4.0 International 


\section{Phaeodactylum tricornutum}

Chris Bowler $^{1, *}$ and Angela Falciatore ${ }^{2}$

${ }^{1}$ Institut de biologie de l'Ecole normale supérieure (IBENS), Ecole normale supérieure, CNRS, INSERM, PSL Université Paris 75005 Paris, France

${ }^{2}$ Institut de Biologie Physico-Chimique, Laboratory of Chloroplast Biology and Light Sensing in Microalgae, UMR7141 CNRS, Sorbonne Université, Paris, France

* Correspondence: cbowler@biologie.ens.fr

Diatoms, key photosynthetic micro-eukaryotes, found in all aquatic ecosystems are classified based on their symmetry into pennates (elongated) and centrics (radial symmetry).

Phaeodactylum tricornutum is a marine pennate species that has become an experimental model used to understand diatom biology. The nuclear genome is chimeric, containing genes derived from ancestral endosymbioses with red and green algae, and enriched by genes acquired laterally from bacteria. Novel combinations of genes enable novel metabolisms, e.g., related to cell wall biogenesis. Together with the genome from the centric Thalassiosira pseudonana (the first to be sequenced) and multiple transcriptomes from other diatoms, it provides the basis for comparative genomics studies and for interpreting the ecological success of diatoms. These studies have revealed little synteny and no major segmental duplications between centric and pennate diatoms, and transposable element mobilization may underlie diatom genome diversification.

\section{Taxonomy and Classifications}

Kingdom: Chromalveolata or CASH lineage eukaryotes (cryptophytes, alveolates, stramenopiles, and haptophytes)

Superphylum: Heterokonta or Stramenopile

Phylum: Bacillariophyta

Class: Bacillariophyceae

Order: Naviculales

Family: Phaeodactylaceae

Genus: Phaeodactylum

Species: tricornutum

\section{Genome Facts:}

- Genome size 27.4 Mb (between 20 and 33 chromosomes)

- 12,233 coding genes

- $\quad 12.3 \%$ repetitive sequences, mainly copia retroelements $(\sim 62 \%)$; including diatomspecific classes (CoDi elements)

- $\quad 5.2 \%$ cytosine methylation, principally in $\mathrm{CpG}$ context

- Diatom genomes are evolving fast (5x faster than metazoans), especially diatomspecific genes. 
- Genome and epigenome browser:

http://protists.ensembl.org/Phaeodactylum_tricornutum/Info/Index

\section{Species Facts:}

- First described by Bohlin in 1897. Formerly known as Nitzschia closterium. The clone of $P$. tricornutum that was sequenced is CCAP1055/1 and is available from CCAP.

- Model organism for diatoms, due to ease of lab growth and genetic transformation.

- Can be transformed by biolistics, electroporation, conjugation. Nuclear and chloroplast transformation is possible.

- Can exist in different morphotypes (fusiform, triradiate, oval, cruciform, round); Changes in cell shape can be stimulated by environmental conditions.

- Ten ecotypes from around the world have been characterized.

- To date no substantial evidence for sexual reproduction.

- Has been particularly useful to reveal insights into diatom $\mathrm{C}, \mathrm{N}$ and Fe metabolism, as well as cell cycle. Utilizes Si facultatively.

- Widely cultivated as food for larval molluscs and fish in aquaculture.

- Considerable interest in using it for biofuels and high value pharmaceuticals.

\section{Fun Fact About the Genome}

Genome contains extraordinarily high numbers of genes encoding cyclins and heat shock transcription factors.

\section{Acknowledgements}

We thank Alessandra de Martino for the confocal image and Alessandro Manzotti for the schematic of $P$. tricornutum shown in the figure.

\section{Literature}

Apt, K.E., Kroth-Pancic, P.G. and Grossman, A.R. Stable nuclear transformation of the diatom Phaeodactylum tricornutum. Mol. Gen. Genet. 252: 572-579 (1996).

De Martino, A., Meichenin, A., Shi, J., Pan, K. and Bowler, C. Genetic and phenotypic characterisation of Phaeodactylum tricornutum (Bacillariophyceae) accessions. J. Phycol. 43: 992-1009 (2007).

Bowler, C., et al. The Phaeodactylum genome reveals the evolutionary history of diatom genomes. Nature, 456: 239-244 (2008).

Allen, A.E., et al. Evolution and metabolic significance of the urea cycle in photosynthetic diatoms. Nature 473: 203-207 (2011).

Tanaka, A., et al. Ultrastructure and membrane traffic during cell division in the marine pennate diatom Phaeodactylum tricornutum. Protist 166: 506-521 (2015). 
Karas, B.J., et al. Designer diatom episomes delivered by bacterial conjugation. Nat. Commun. 6: 6925 (2015).

Bailleul, B., et al. Energetic coupling between plastids and mitochondria drives $\mathrm{CO} 2$ assimilation in diatoms. Nature 524: 366-369 (2015).

Nymark, M., Sharma, A.K., Sparstad, T., Bones, A.M. and Winge, P. A CRISPR/Cas9 system adapted for gene editing in marine algae. Sci. Rep. 6: 24951 (2016).

Rastogi, A., et al. Integrative analysis of large scale transcriptome data draws a comprehensive landscape of Phaeodactylum tricornutum genome and evolutionary origin of diatoms. Sci. Rep. 8: 4834 (2018).

Serif, M., Dubois, G., Finoux, A.L., Teste, M.A., Jallet, D. and Daboussi, F. One-step generation of multiple gene knock-outs in the diatom Phaeodactylum tricornutum by DNAfree genome editing. Nat. Commun. 9: 3924 (2018). 


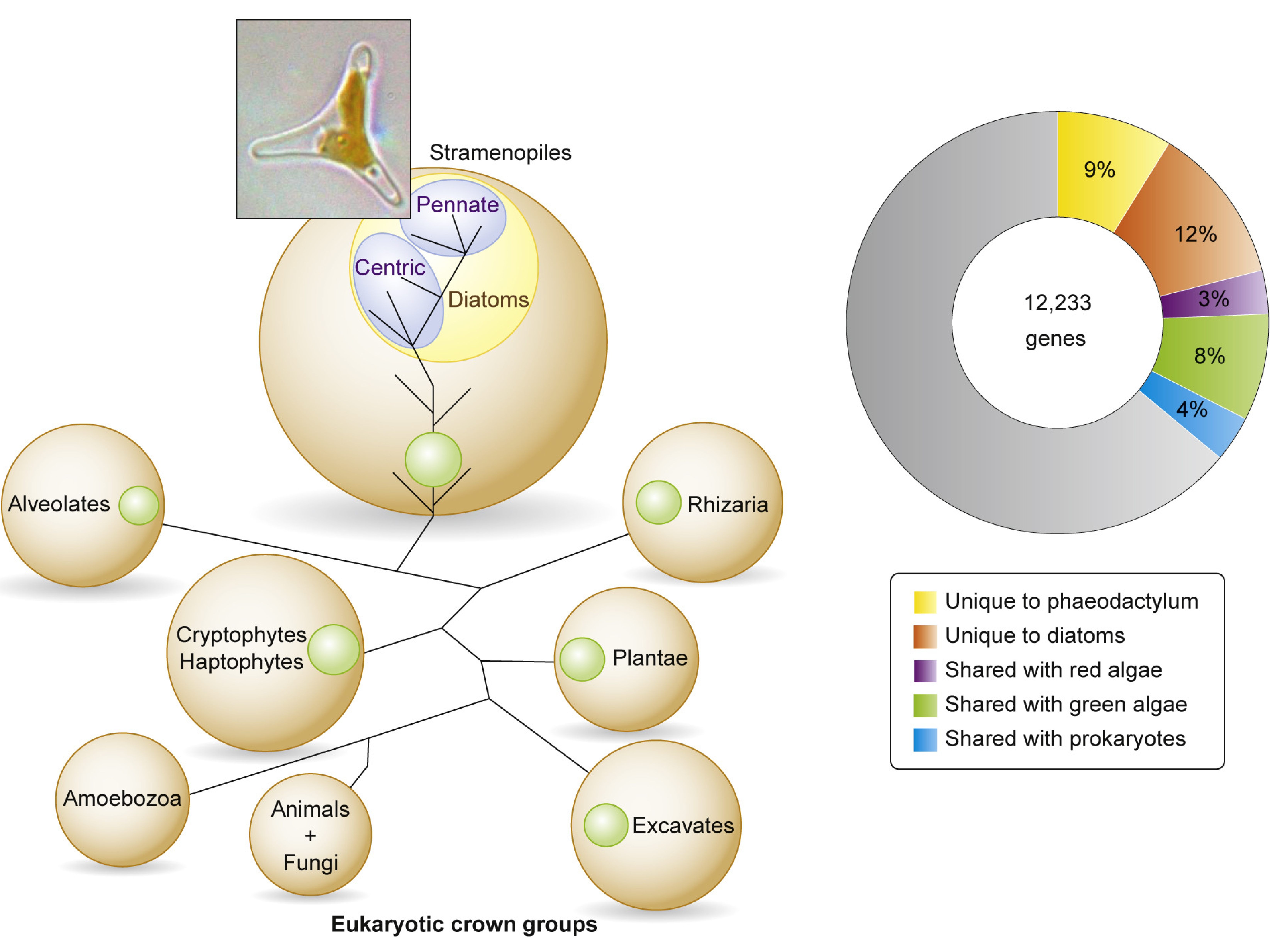

Group contains photosynthetic representatives 


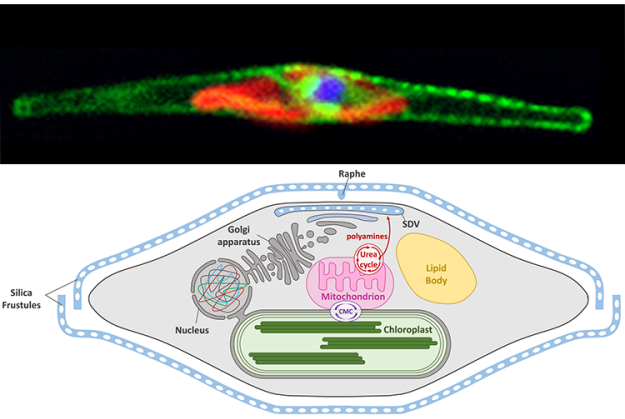

